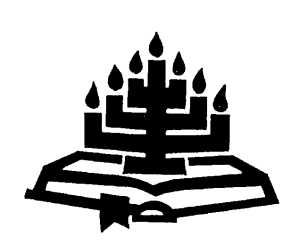

\title{
Luther's moral synthesis: occamism, Christian mysticism and the idea of being
}

\author{
A. Raath \\ Department of Constitutional Law \& Philosophy of Law \\ University of the Free State \\ BLOEMFONTEIN \\ E-mail: raathA.RD@ufs.ac.za
}

\begin{abstract}
Luther's moral synthesis: occamism, Christian mysticism and the idea of being
\end{abstract}

To Luther human beings can only come to true redemptive knowledge through the Word and through faith. Although philosophical knowledge in the domain of man's earthly existence cannot provide him with true knowledge in matters of faith, such knowledge is of much importance for man's earthly existence from a moral point of view. By submitting to universal being even unbelievers can gain valuable insights into moral matters. Such moral insights are important for making human co-existence possible in society. Within the broad context of Luther's Occamist views on knowledge, both German mysticism and the Stoic-Ciceronian idea of being contribute towards a synthesis from which Luther's views on morals in matters of faith and philosophy respectively emanate.

\section{Opsomming}

Luther se morele sintese: okkamisme, Christelike mistiek en die idee van syn

Vir Luther kan die mens slegs tot ware verlossende kennis kom deur die Woord en geloof. Alhoewel filosofiese kennis op die terrein van die mens se aardse bestaan hom nie in staat stel om tot ware kennis in aangeleenthede betreffende die geloof te kom nie, is sodanige kennis vanuit 'n morele oogpunt beskou van groot belang. Deur die agting vir universele syn kan selfs ongelowiges waardevolle insigte in morele aangeleenthede verwerf. Sodanige morele insigte is belangrik vir die menslike saambestaan in die samelewing. Binne die breë konteks van Ockham se standpunte oor kennis, lewer sowel die Duitse 
mistiek as die Stoisyns-Ciceroniaanse idee van syn 'n bydrae tot ' $n$ sintese in Luther se morele en filosofiese denke.

\section{Introduction}

The post-World War II era witnessed a host of important studies on Luther's philosophical and moral views and their relatedness to his theology. Hägglund's work, Theologie und Philosophie bei Luther und in der Occamistischen Tradition (1955), contributed significantly towards appreciating Occamist tendencies in Luther's writings on the relationship between philosophy and theology, ${ }^{1}$ whilst Hoffman's 2 studies on Luther and the mystics added further insights towards a better understanding of Luther's religious commitments and the philosophical and moral implications thereof. 3

A closer scrutiny of Luther's approach to nature, ethics and the political co-existence of human beings also reflects other influences (and/or parallels) that could broadly be described as being "Stoic" in nature, and more specifically, Ciceronian in substance. In the areas of morals and duties, the Ciceronian parallels in Luther's thought include the divine authority binding everything in the order of creation together by means of a law, which is reflected universally as a manifestation of reason, the elements of human responsibility, duty and freedom contained in the divine providence, and the universal divine law which holds everything in the temporal sphere in its bonds. To these broad trends could also be added Luther's reflections on human virtue in the order of the world, that obedience to God is freedom and that virtue consists in conformity to the order of things.

The inter-mingling of Ciceronian tendencies with elements of Occam's distinction between theology and philosophy 4 and mystical elements from Tauler and other German mystics, make a systematic

1 Note e.g. Luther's statements to the effect that philosophy concerns the knowledge of the human reason, whilst theology is involved with that which is apprehended through faith (WA, 39(2):6, 26).

2 See e.g. Hoffman $(1975 ; 1976)$.

3 For the influence of Christian mysticism on the Reformation and other Christian movements, see Johnson (1988:1-24).

$4 \quad$ Hägglund (1955: Preface) points out that Luther has links with nominalism. He adds that, in a wider sense, Luther is linked both "positively" and "negatively" to Scholasticism. 
description of Luther's philosophy of ethics very complicated, if not virtually impossible. In spite of such obstacles, however, this article briefly reflects on some of the mystical and Ciceronian elements interwoven with Luther's theological and philosophical views on ethics. It has to be borne in mind, however, that Luther's moral theory may harbour additional elements from nominalistic quarters; and that the possibility should not be excluded that the German mystics could also have been influenced by Ciceronian moral philosophy. 5

\section{Luther, the German mystics and the Frankfurter's impact on Luther's moral views}

\subsection{Mysticism in the Theologia Germanica}

Through the work of Hoffman in particular, a greater sensitivity for and awareness of the mystical elements in Luther's thought were introduced into discourses involving Luther's theological position and his moral views. ${ }^{6}$ In an article Hoffman (1974:316-329) states two reasons for his interest in the theme of Luther and mysticism: firstly, because there should be an alertness to the "stronger and stronger minority scholarship" which lifts out precisely the experiential and spiritual elements in Luther's thought on Christian faith; and secondly, because there should be an awareness of the "unconscious censorship" which has often been applied to interpretations of Luther's thought.

One aspect of a "threefold censorship" mentioned by Hoffman $(1974: 318)$ is the idea that there must be a contra-distinction between Protestant theological positions and Roman Catholic theological propositions at every important dogmatic point. This, says Hoffman (1975:23), is a schema which, "not least in Protestant theology", bars us from taking Luther's links with the medieval mystics very seriously.

Hoffman (1974:318) argues further that due to the "Melanchthonian spirit" in Luther's research, interpretations of Luther's thought tend

$5 \quad$ Note e.g. Bernhart's (1966:87, 130, 133, 251 n. 23 \& 279 n. 534) comments on Cicero's influence on the philosophical mysticism of the medieval period.

$6 \quad$ For purposes of this essay Hoffman's description of the meaning of mysticism is applied, i.e. that in some way or another, humans receive "intimations and incentives about the parasensible not wholly mediated by physical sensation, psychological common sense, or logic" (Hoffman, 1975:22). 
towards "intellectualistic doctrinarism" - thereby turning towards a system of notions, rather than being sensitive to the "spirit" of Luther's thought (cf. Hoffman, 1975:23). To Hoffman the results were that Luther's references to spiritual experience, feelings concerning God's presence and his allusions to "kinship with some friends in the Spirit called 'mystics'", were left out of consideration (Hoffman, 1974:319). ${ }^{7}$ Hoffman's work on Luther's mysticism adds an important element to a better and more comprehensive understanding of Luther's socio-moral views, hitherto unattended to.

In this article it is argued that within the Occamist structure of Luther's views on theological and philosophical knowledge respectively, both the Christian mysticism reflected in the Theologia Germanica and the Ciceronian perspectives on moral duties represent important segments of Luther's distinction between the true knowledge of God attained through the human being's union with Christ, and the knowledge gleaned from submitting to the light of being respectively.

Significantly, in his publication of the Theologia Germanica (TG) in 1518, Luther reflects on the knowledge to be obtained from this anonymous manuscript. He writes that next to the Bible and Saint Augustine, no other book has come to his attention from which he has learned - and desired to learn - more "concerning God, Christ, man, and what all things are" (TG, 1980:54). 8 Why was Luther

7 An important additional reason, says Hoffman (1975:23), is situated in the fact that much theology, "both of liberal and neoorthodox persuasions", borrows knowledge criteria from an academic scientism which still thinks largely in "Kantian and Newtonian verifiability terms". The result is that intellectualistic preconceptions in the Western Enlightenment tradition bar many scholars from seeing the central significance of Luther's "experiential-mystical language".

8 In a letter by Chevalier Bunsen to the translator of the Theologia Germanica in 1854, he expresses his regard of this mystical source as follows: “... with Luther, I rank this short treatise next to the Bible, but, unlike him, should place it before rather than after St. Augustine." He adds:

\footnotetext{
Like the saint of Athens (Socrates), ... they (the Dominican 'Friends of God') spoke plain truth to the people. To their disciples, and those who came to them for instruction, they exhibited the whole depth of that real Christian philosophy, which opens to the mind after all scholastic conventionalism has been thrown away, and the soul listens to the response which Christ's Gospel and God's creation find in a sincere heart and a self-sacrificing life - a philosophy which, considered merely as a speculation, is far more profound than any scholastic system.
}

The work of the Dominicans, says Bunsen, paved the way for that spiritual philosophy of the mind, of which Kant laid the foundation (Bunsen, 1854). 
attracted to the contents of this mystical source at the advent of his theological transformation? Firstly, because the primary concern of the Frankfurter in this manuscript is to come to true knowledge of God and the whole of creation through union with Christ. In other terms: so that mankind can come to know what the Absolute Good is. Secondly, because he maintains that man can come to a real union with God through the Word and God's Spirit; and thirdly, the Theologia Germanica links man's moral existence in the worldly order to man's true knowledge and union with the Absolute Being of God. 9

\subsection{The true light, the false light and union with God}

A central theme in the Theologia Germanica is that false knowledge in the moral domain is the result of the human subject's selfcentredness; and that false moral knowledge reflects egoistic selflove. This false light is of the natural order and nature - its characteristics are everything in the natural world: "l", "mine", "me" and so forth. Therefore, if one is to come to inner knowledge of the one truth, the "I" and the "mine" must depart and get lost (TG, 1980:123). The true light (God's Spirit) illuminates the mind to true knowledge, whereas the false light is self-centred and reflects egoistic self-love. Only the true light is able to bring man to submission to God's absolute Being and all created being. Whilst the true light reflects true knowledge, 10 the false light of natural reason contains false knowledge. It is the mark of the natural false light that it is avidly bent on as much learning as possible. It derives much pleasure, joy, and glory from its schooling and knowledge. In fact, says the Frankfurter, the natural light is composed of knowledge and nothing else; this natural light is concerned about itself and the things of the self. Natural man thinks he richly deserves all good things that come his way and he believes he has a right to everything; he is convinced that he has risen above all the things of the world, that he has conquered and so forth; he even looks on himself as having transcended Christ and the Christian life (TG, 1980:124). The false

9 Cf. Johnson (1985:25) for the fact that the Theologia Germanica itself is representative of "late medieval synthesis".

No one may think that he can come to this true light or true knowledge, or to the life of Christ, by much questioning or by hearsay, or by reading or studying; nor by great and high science and mastership, or by high natural reason. 
light and the false, deluded love provide knowledge and measure learning, but no love emerges from within - knowledge and learning are indeed more loved than that which is the object of knowledge (TG, 1980:124).

If someone loves another person because of that person's possessions, or if we love God for the sake of a certain thing we want to possess, that is all love gone astray (TG, 1980:125). True love is informed and guided by the true light and knowledge; it requires love to embrace nothing but the simple, perfect Good (TG, 1980:128). When true light and true love are present in a person, the true perfect Good has come to be genuinely known and loved for its own sake (TG, 1980:126). Therefore, if you wish to love God "you shall love all things in one as the One, yet all, and you should love the One in all as One" (TG, 1980:134).

In the Theologia Germanica it is stated that God is also a light and inner knowing, whose nature is to shed light, to shine and to know, for God is light and knowing. 11 He must emit light and knowing, and all this giving and knowing is God, apart from the created world. 12 Whereas dwelling in God produces the effect that all things dwell as beings more truly in God, hell is and consists in self-will! (TG, 1980:136). Wherever there is a person in whom the will is not enslaved but remains noble and free, there we deal with a true, free, unfettered being of the kind about which Christ speaks: "The truth will make you free" (John 8:32, 36).

Only through union with the eternal Good can man be really and truly free, because the exalted Goodness cannot be anything of that which a created being as created being may grasp and understand (TG, 1980:145). A person is drawn into and enchanted by the union with the eternal Good. ${ }^{13}$ The Father is the one who draws; man is

11 For the true light as the Holy Spirit in the Theologia Germanica, cf. Johnson (1985:37). When the Theologia author refers to the Light enlightening man, he is speaking of the Spirit's actions.

12 This comes close to Aquinas' statements on "supernatural God-knowledge". That is to say, from man's point of view, the human subject shares in God by recognising God interiorly.

13 Luther translates this into bridal terms, described as a "secret wedding". The soul is like a bride who relies on her bridegroom (WA, 22:640.40 (Dictata on the Psalms 1513-1516) and WA, 43:581.11 (Lectures on Genesis)); the church is as a channel for the bridegroom's love (WA, 39:1; 3:24-29). The intimate union of the human being and Christ is made possible by the Word; the Word "beckons 
being taught by the same One who seeks him so that he cannot come into the union except through the Christian life (TG, 1980: 146). When the human subject "tastes" the perfect Being, as far as that is possible in an earthly life, all created things, yes, even his own self, become like nothing to him (TG, 1980:147).

\subsection{Luther on being and true moral knowledge}

\subsubsection{The Christian life and the quest for true knowledge}

Hoffman (1976:9) surmises that his work on the mystical and on Luther led him increasingly to appreciate the close relationship between the moral and the mystical in Luther's thought:

Rational decision-making in much contemporary Christian ethics tends to disregard the unique source of power available to the Christian and depend almost exclusively on criteria provided by the social sciences.

The result, says Hoffman (1976:9), is that Christian moral responsibility is discussed within the framework of the belief that existence precedes essence. He concludes that this dependence obscures the Christian ground of moral responsibility which inspires cross-bearing and cannot be limited to purely rational considerations. ${ }^{14}$

toward a union with God in the depth of man's innermost" (Hoffman, 1975:26). The Word carries the "sense" or mind of faith, which is quoted by the Spirit. The literal Word cannot be understood unless the spiritual enlightenment takes place (WA, 4:492.5-8). Whereas the externally given Word is the instrument of Him who writes living words in the hearts, the Spirit is hidden in the letter (WA, 3:255.41-256, 38 \& Hoffman, 1975:26). The words of the gospel carry with them justice, virtue and salvation so that the gospel becomes an instrument of the Spirit by which God renews the human person (WA, 9:440.6-19). True faith is the invisible influence/work of the Holy Spirit (WA, 40:3, 738.4 ff.); it is elevated above the rational reading only of the gospel (cf. WA, 10:1; 1:387.5-14 \& Hoffman, 1961:321). The human subject becomes inseparably united with Christ (WA, 5:549.40); the church is also our mystical body (WA, 56:60-61; WA, 3:150.16 ff.). The human being's inner experience produces important results for his moral existence in the world.

14 Also note the remarks by Hägglund (19557:93, 94) and Hoffman (1975:21-35) at 21. Hägglund (1955:93-94) observes that it is not only a matter of "a certain similarity of thought", but also a matter of "profound impressions and impulses from mystical writings". Elsewhere Hoffman (1975:27) puts the moral implications of a Christian life in union with God as follows:

As theology is more than mere thought, so ethics is more than mere rational decision-making. In other words, Luther did not confine the ground of ethics to material reality and rational consciousness (about Christ or anything else). They play their part but the power and the 
What are the implications of Luther's mystical views that the Christian "experiences" God's presence rather than rationally determining God's involvement in the Christian life?; that Christian ethics, rather than being rooted in rational decision making, is based on a Lord who provides strength for moral responsibility? Although human beings have to apply scientific verifiability codes and dress their opinions in rational language, the ultimate source of moral responsibility is the Lord's mystical presence rather than rational calculations. 15 Hoffman (1976:245) describes the essence of the mystical union with Christ in the following terms: instead of being guided only by the calculated prudence of the humanly possible, the person mystically communing with Christ is in touch with a world which gives strength for the humanly impossible. Thus, the ethics of mere cognitive considerations has little understanding for the mystery of crossbearing, turning the other cheek, walking the second mile, aiding the thankless: in a word, "vicariousness" (Hoffman, 1976:235).

The concrete effects of the mystical in Luther's moral thought carry with them vast implications: firstly, the ground of ethics is not to be confined to material reality and rational consciousness (cf. Hoffman, 1975:27); the ethical is not grounded in speculations or rational concepts but in a "living Lord" whom Christians experience in their daily living (cf. WA, 45:542; LW, 24:90 (SJ III)). Luther relates his experience of Christ's humanity and divinity in the following terms:

I have realized in my being that the article (about Christ's humanity and divinity) has been preserved for more than one thousand years over against all clever minds. (WA, 45:542; LW, 24:109-110 (SJ III).)

Secondly, only union with God, through Christ, provides true knowledge and insight. 16 Through the Word and faith Christians are

incentive for moral commitment stem from the transrational Presence of Christ.

15 Elsewhere the Frankfurter (TG, 1854:15-16) quotes from Dionysius that for the contemplation of divine knowledge, the human subject should abandon the senses and reason; "and pass out of thyself, and give up all knowledge of all the aforementioned things, and come into union with that which is above all creatures and knowledge".

16 Note Frankfurter (TG, 1949:95-96) regarding the statements on the moral implications of man's becoming united with God, being both a process of unity, incorporating, grafting and a state of being, a condition; it is

the point of convergence of all the forces of the soul and hence the undifferentiated, self-contained source of cognition and love [which] 
united to God in true knowledge and understanding. Thus the works of Christ, says Luther, are practically being channelled through Christians to the world and societies they live in. Christ has risen into command of the whole invisible realm and "works His wonders through Christians, by their proclamation ... prayers and works of mercy" (WA, 24:537-539; LW, 24:85-86 (SJ III)). Hoffman provides a useful list of very important moral implications flowing from the Christian mystical moral life: the inner union with Christ which is the mystical element in justification by faith is also the wellspring of moral life and can be experienced by the human subject; the "extraordinary" anchorage of the moral does not exclude the common sharing in the ordinary life of the world; $\mathbf{1 7}$ the formation of a Christian life from within spiritual communion with Christ involves active service and the doing of justice; man's sinfulness is not the total truth about him, for through Christ we may speak of the "good in us"; in the spiritual union with Christ a paradoxical tension exists between suspension of the law and a new confirmation of the law; it is a mystical truth that true Christians play a central moral role in the world (Hoffman, 1975:27-32). 18 The implications of moral commitment stemming from the "transrational Presence of Christ" in Luther's thought are far-reaching. Firstly the moral is rooted in the mysterious, powerful, living Lord (WA, 45:560.21-28; LW, 24:109110 (SJ III)). Secondly, the inner union with Christ which is the mystical element in justification by faith is also the wellspring of moral life, because works of love flow from faith (WA, 45:594-596; $L W, 24: 146-147$ (SJ III)). Thirdly, the mystical union with Christ does not exclude peaceful co-existence in the ordinary life of society (WA,

produces that which is of ultimate significance of mystic poetry: knowledge through love, love through knowledge, a union with God in which the intellectual and ethical capacities of man, merged in the higher Unity, are beatified by attaining the same Object. Speaking sub specie Dei, it is the eternal, ever-flowing stream by which He imparts Himself to man. In it, God and man meet and are made one ...

17 The union with God amounts to "partake" in the divine nature; to "partake" means to be "imbued with or illuminated by the Eternal or divine Light, and inflamed or consumed with Eternal or divine Light, and inflamed or consumed with Eternal or divine love; he is a godlike man and a partaker of the divine nature" (TG, 1874, Ch. 41).

18 Hoffman (1975:21) explains the moral implications of justification through faith in Luther's thought as follows:

$[\mathrm{T}]$ here is a mystical dimension of Luther's experience and thinking about justification which presupposes the extraordinary, the supernatural and the eternal in order to bring structure to the ordinary, the commonsensical and the temporal. 
40:1, 289-290; LW, 24:249-250 (SJ III)). Fourthly, Christian union with Christ involves active service and doing of justice (cf. WA, 45:688-689; LW, 24:249-250 (SJ III)). Fifthly through Christ we may speak of the "good in us" (cf. WA, 45:649; LW, 24:207 (SJ III)). In short we may summarise Luther's views contained in his statements concerning the Christian and non-Christian uses of the world as follows: although a Christian uses the world in such a way that there is no difference between him and non-believers, there is indeed the greatest possible difference, because human beings do indeed live in the flesh, but they do not live on the basis of the own self. What the Christian speaks proceeds from another source because he has been touched by the Holy Spirit - the unspiritual man does not perceive this, he does not know where the words of the spiritual man come from. Although participating in the common tasks and duties of all men, the converted spiritual man is the conveyor of moral truth from Christ (WA, 40:1, 289-290; LW, 26:171-172 (LG I)). Hoffman (1975:30) rephrases it succinctly:

The big difference is Christ. He provides the force that creates 'good in us'. Good moral fruits issue from 'remaining in Him'. Moral duties outside Christ do not have the same source and context: for a person hidden in Christ, the light falling on whatever societal duty or special task of mercy gives off rays of goodness. But the goodness is Christ's, not the individual's. You are converted to delight in Christ's goodness and in the power He communicates. Thus it is theologically proper to speak of the 'good in us' as long as we do not consider it our own doing. Ethical goodness begins in humility and continues in disciplined action.

What are the concrete moral implications of following the true light? The Frankfurter grounds the moral life in a personal disposition. He describes teleological morality as legalism, as too heavy dependence on law. The freedom of a Christian person is anchored precisely in that union with God which engenders freedom (TG, 1980: 100). ${ }^{19}$ To do away with the Christian life as well as commands and laws, rules and order, and pay no heed to them, despise them and scoff at them, is a "falsehood and a lie" (TG, 1980:100). The good of God, without creatures performing God's will, is nothing but being and beginning without deeds (TG, 1980:103). On the other hand: the 
more man follows after and grows in self-will, the further he is from God and the true Good (TG, 1980:106). ${ }^{20}$

The moral duty resulting from following the true light consists in the fact that God and all creatures have a right over and claim on the person who abides in God, but that creature has no right to them the human subject owes debts to all things, no one owes me anything - therefore man's primary moral duty resulting from the idea of being is the duty to do all things for others (TG, 1980:107).

The Frankfurter emphasises that because God is Absolute Being, 21 he is above and without rules, measure and order, yet renders to all things rules, order, measure, and rectitude. However, all of these structures were ordained by God to follow and obey in the moral order of temporal existence (TG, 1980:108). 22 Furthermore, he distinguishes four different kinds of people who deal with order, commands and rules. The first group of people lead an ordered life neither for God's sake, nor out of a particular personal desire, but simply because they are compelled - they do the least possible and it all turns sour and burdensome for them. The second group observes laws and rules for the sake of reward. They are people who know nothing beyond this perspective and fancy that one can and will in this and no other way obtain and earn the kingdom of heaven and eternal life. They consider that a person who neglects and omits even some little rule as lost to the devil - they show great seriousness, and diligence to boot, yet it all turns sour for them. The third group are the wicked and false spirits who fancy themselves as perfect, and speak accordingly - they imagine that they are in no need of rule and law and in fact scoff at all talk about order (TG, 1980:113). The fourth are the illumined ones, guided by the true

20 Sin is the creature turning itself from the immutable Good to the mutable, that is, from the Perfect to the part or imperfect, and above all to itself" (TG, 1854:4).

21 God's perfect Being is described in typical Aristotelian terms as the "Perfect".

A Being that has in his being all things comprehended and included, without whom and out of whom there is no true enduring being, in whom all things have their existence; for he is the essence of all things, and is in himself unchangeable and immovable, yet changes and moves all other things. (TG, 1854:1.)

22 Cf. TG (1901:108): "But that other thing which they affirm, how that we ought to throw off and cast aside the life of Christ, and all laws and commandments, customs and order and the like, and pay no heed to them, but despise and make light of them, is altogether false and a lie." Also note the remarks of Tinsley (1952:84-88, at 86). 
light; they do not practice the ordered life in expectation of reward for they do not want to acquire anything with the aid of it, nor do they hope that something will accrue on account of it - they do what they do in the ordered life out of love (TG, 1980:113). Those illumined by the true light keep to the middle - between those who seek reward and those who scoff at law and order. They maintain a posture between the ruthless indifference of the free spirits and the anxious concern out of a desire for reward.

The moral posture needed for transmitting the true light into deeds of moral good is based on love. The inner recognition of the light is nothing, "or is good for nothing" without love - a person may have an excellent knowledge of the difference between virtue and wickedness, yet if he does not love virtue he is not truly morally good. But if he loves virtue, he obeys it and his love renders the immoral an enemy. He simply cannot indulge in it - he hates the immoral in all humans and his love for virtue prompts him to practise and do moral good wherever he can. He does it without concern for reward or the why and wherefore of personal ends; he does it only because virtue is part of his love (TG, 1980:121). The Frankfurter comments as follows on the love of virtue as virtue:

Virtue becomes for such a person its own reward. He is well content with this and does not accept treasures or riches in exchange. Such a person is or becomes truly moral. A genuinely moral human would not accept the whole world if it might mean being immoral. No, he would rather die a miserable death. (TG, 1980:121.)

The Frankfurter subsequently applies the same principle to justice (Gerechtichkeit) and injustice (Ungerechtichkeit) in a socio-moral context (cf. Hoffman in TG, 1980:184 n. 177). Many people know fully well what right and wrong are, yet are not or will not become righteous thereby. When the human subject does not love justice he/she actually practises wickedness and injustice. But if a person loves justice he would simply not wish to act unjustly. Thus, if he is the enemy of injustice, he becomes prepared to suffer and act vicariously wherever he detects unrighteousness in a fellow being, "striving to remove the unjust condition and restore the wrongdoer to righteousness" (TG, 1980:121). The truly just would rather die than cause injustice and this for no other reason than for the love of justice. Justice becomes the reward for the truly just: "she gives herself as reward". This is how a just person lives - he/she would rather die a hundredfold than live unjustly (TG, 1980:121). 
True love of God and the things of God are needed to become sanctified or divinised. If true benevolence is to be united with knowledge, man must cling to God and let go of everything that is not God or is not of God.

And whatever form the latter takes, he is its foe and adversary. It goes against his grain and is for him an affliction. This love unites man with God in such a manner that he nevermore will be separated from it. (TG, 1980:122.)

The Christian's attachment to God produces excellent moral fruits:

... but chiefly whatever is ascribed to God, what appertains to God, or is God's own, as goodness, virtue, truth, peace, love, righteousness, and the like, thereafter should the outer man direct himself, and what is against these, that should man despise and flee (TG, 1854:11).

\subsubsection{The light of being and man's moral life}

\subsubsection{The light of being and moral knowledge in the order of creation}

Does this mean that non-Christians are not able to act virtuously or that they are not able to perform morally good actions? Does it further mean that only Christians are able to make meaningful moral contributions to human existence in the world and in society? Luther's answers to these questions are in the negative. Even though human beings may not be committed Christian believers, they may have the ability to have sound moral insight and produce good moral fruits. Luther's views contain two important elements: firstly, God's revelation concerning the way in which human beings should behave extends to the whole of mankind. Second, even in the absence of a true "unification" with God, the human subject may still have an abstract knowledge of the Being of God and created beings, demanding acknowledgement and submission as required by the moral law and revealed to the whole of mankind. Submission to the revelatory power of God's Being and created being - the idea of which exists a priori in the human mind - produces moral consequences in the socio-moral sphere with good results for the whole of mankind. At this point in Luther's Occamist system of knowledge, the Stoic (particularly Ciceronian) idea of being surfaces prominently.

Within the various contexts of the problem of attaining knowledge of man's spiritual destiny and his role in the concrete reality of earthly 
existence, the Frankfurter focuses in the Theologia Germanica on the various manifestations of the universal being emanating from God's Absolute Being: divine Being, 23 created being, the ground of being and the attachment of man's created being to the Absolute Being of the divine. In a general sense it could be said that the Frankfurter investigates the idea of being innate in the human subject juxtaposed to the human "self" or "I-ness". The idea of being is intuited as a light of the mind, without reducing it to an immanent, subjective form of human reasoning. It is this transcendent, objective form, manifest as the idea of being, which provides the basis for the Frankfurter to investigate the conditions for attaining true knowledge in the earthly realm.

In a general sense one could distil three central themes connected to the idea of being in the Theologia Germanica. Firstly, the central, most universal level of reflection for attaining philosophical knowledge manifests itself in acknowledging being in its various orders. Secondly, the idea of being in human intelligence is intuited as a light of the mind in a transcendent form illuminating the eyes of the beholder. Thirdly knowledge of the Whole and the Good, albeit in an abstract form, leads to detachment of self (or I-ness) and produces concrete effects in man's moral life relative to the acknowledgement of the Absolute Being of God and created beings.

Central to the Frankfurter's discourse in the Theologia Germanica is the idea of God's Absolute Being - God is the complete Being, representative of the highest and absolute Good. All created being in the world is dependent upon the Absolute Being of God - whereas God is the complete Being, man is the creature of God. The first step in the process of acquiring moral knowledge is to submit to and acknowledge all manifestations of being for what they are. In Chapter 21 of the Theologia Germanica the Frankfurter formulates the submission of man as a "submission to God and to all things", that is to say, "to God, his own self and all creatures" (TG, 1980:57). If man wishes to obtain true knowledge, or, as the Frankfurter puts it, "(i)f the soul is to gaze or look into eternity", the human being has

23 Bernhart (in TG, 1949:113) uses "Essence" for God's Being. In the original the word Wesen (being, existence, essence, substance, intrinsic value, quality, nature, etc.) is used. Although the Frankfurter's doctrine is philosophically vague and contradictory, its basic concept - that things have their being from God and that the sphere of the divine influence extends to all that is - sufficiently answers its purpose of edification (Trask in TG, 1949:223 n. 3). 
to be detached from all created things and, above all, from the claims of self" (TG, 1980:68).

The submission to being (including regard for and appreciation of being) carries with it respecting God's Absolute Being and acknowledging all created being as the products of God's works in the temporal realm. The submission to being entails firstly the regard for God as the absolute Being - God is the perfect Being. He is comprised and embraced in Himself and His Being all that is. Without His Being and outside of it there is no true being and in it all things have their being since it is the core of all things (1 Cor. 13:10; TG, 1980:60). God is complete Being - He is true Being (TG, 1980:61); His glory He gives to no other (Is. 42:8; 48:11; TG, 1980:63).

In contradistinction to God's perfect Being, man's created being is incapable of "discerning, comprehending, naming and formulating" that which is perfect. Man fancies himself to be what he is not. He fancies himself to be God, yet he is only nature, a created being. From within that illusion he begins to claim for himself the traits that are marks of God. He does not claim only what is God's insofar as God becomes man or dwells in a divinised person - no, he claims what is innermost of God, God's prime mark, namely His uncreated, eternal Being (TG, 1980:115).

How is the human subject's knowledge of being possible? Firstly, the Frankfurter implicitly applies the principle that the intelligibility of being is dependent upon the union of man's intellective capacity with being as the object. Secondly, the human subject's encounter with being is generally guided by the self-manifested (or self-revelatory) power of being - being shines in the human subject with such power that he cannot oppose what he sees. In effect it means that being acts as something intelligible and, as an objective power, demanding from the human subject to be understood.

Submitting to God and created being universally is only possible through love for and benevolence to cherish all creatures and to wish the best possible for them. This love for and benevolence to being is only possible through true humility rooted in the ground of his being and where there is "a poverty of spirit" (TG, 1980:57). This is the first step in the subject's encounter with Absolute Being and created being in the quest to attain cognitio mutatina (morning knowledge) of the divine, and not cognitio vespertina (evening knowledge) only (see Hoffman in TG, 1980:166 n. 44). 
Human beings, to the extent that they intuit being, are endowed with intellect. This intuition of being takes place on a truly transcendental level. To the measure that the human intellect shows the ability of receptivity, the human understanding receives intellectual light - the light of reason for guiding the human understanding to moral knowledge. In effect, therefore, the process of acquiring true knowledge does not start with the human subject but with the object of being. The human mind does not produce its own light, but to the extent that it intuits being it receives the light, and the power of being is kindled in the human intellect. The first act by which the intelligent principle intuits being, that is, receives the cognoscitive light, is the result of the self-testifying power and light of being.

For the human subject to acquire knowledge, it is important to note that God's Absolute Being and created being constitute the two dimensions of being of that which is presupposed in all other knowledge - if the human subject did not know what existence was, the human mind could not think of anything at all; nor could the human subject reason, since every object of human thought is an entity, a real or possible thing. Furthermore, if being is known of itself, it cannot be defined - it has to be granted that it is known prior to any reasoning whatsoever. The intelligibility of being as known being contains the property and nature of light of mind in the human subject.

Also in Luther's early reformational work we find a priori (or supernatural) elements of faith, knowledge and anthropological examples about God's inner space in man - the inner space in Luther's thought is that "knowledge of God" which is divinely imprinted upon all men's minds (WA (Tr), 5:368; Hoffman, 1976:138). In his Table talk, Luther describes the revelatory power of the idea of God's absolute Being in the human mind as follows: "The knowledge of God is divinely imprinted upon all men's minds. Under the sole guidance of nature all men know that God is, without any acquaintance with the arts or sciences." Luther proceeds:

There has never been a people so wild and savage that it did not believe that there is some divine power that created all things. And thus it is that Paul says: 'The invisible things of God from the creation of the world are clearly seen, being understood by the things that are made, even his eternal power and godhead.' ... Although men ... have lives just as though 
there were no God ... the conscience ... testifies that God is (WA (Tr), 5:368. no. 5820; also cf. Otto, 1975:94-108). 24

What does it mean for being to dwell in God? The mystical undertones of the Frankfurter's views reflect the idea that since God created the world, the world has its essence in God more truly than in itself (TG, 1980:134). In later reformational thought this mystical "participation" in the being of God is explained in terms of that "image" of God in man which is "stirred" by the impact of God's love and grace - hence we say that all things are good according to their innermost being.

The Frankfurter's statements to the effect that natural reason is itself forced by the revelatory power of being to acknowledge being within its order (or the nature of things) find two important parallels in Luther's thoughts on man's natural endowment with knowledge of God's existence: Luther appeals to "reason's call" and the human subject's sense of the divine ("syntheresis") (cf. WA, 51:2.1 \& 113: $5)$, culminating in the human subject's natural reason being forced

... even here where there is no holy scripture to grant it [namely the truth that the general human reason possesses many true cognitions of what 'God is in himself or in his innermost essence'], convinced by its own judgement. For all men, as they hear it treated of, find this belief written in their hearts, and acknowledge it as proved, even unwittingly: first, that God is omnipotent and can neither err nor be deceived ... These two things are admitted by heart and feeling (WA, 18:719.20-26); LW, 33:191 (CR III); trans. Otto, 1975:138 n. 1).

Luther also subscribes to the existence of an idea of being, a knowledge of God pre-naturally impressed upon man's mind (or intellect), and assuming that in the order of nature (or creation) all human subjects know that God is, without any acquaintance with the arts and other fields of science, because the human subject's very denial of God is a concession that God is - to Luther, no human subject can deny that of which one has no knowledge. Luther states:

Luther steht dem Gedanken einer den Menschen von Anbeginn gegebenen (Allgemeinen Offenbarung) nicht gegenüber. Was man von Gott wissen kann, ist also wirklich offenbart.

He refers to Luther's statements in WA (39(2):14-15). 
Wherefore all the Gentiles knew that there is a God, however much they were Epicureans, however much they maintained that there is no God. Did they not confess God's being in that very denial of Him? For no one can deny that of which he has no knowledge. Wherefore, although men have all their lives been occupied in the greatest sins and crimes and have lived just as though there were no God, yet they have never been able to cast forth from their minds the conscience that testifies and affirms that God is. And although that conscience has been overborne for a time by evil and perverse opinions, yet it comes back to convict them in their life's final breath. (WA (Tr), 5:368.20-36; 25 trans. Otto, $1975: 139$ n. 2.)

In effect this implies that although God can only be truly known through the light of the Word and the Spirit, all human subjects have a general, albeit dim and abstract, knowledge of the existence of God and his creation.

\subsubsection{The idea of universal being and the moral insights of non-Christians}

At first glance the Frankfurter's discourse in the Theologia Germanica maintains a dialectical structure juxtaposing the perfect life and knowledge from man's imperfect existence and false knowledge in the world. The insurmountable contrarieties between the perfect and the imperfect, and the true knowledge and the false knowledge culminate in a number of apparent dialectical opposites: that which is perfect and that which is in part (TG, 1949:I); the two eyes of the spirit with which man looks into eternity with the one and into time with the other (TG, 1949:VII); how a righteous man in this temporal world is brought into hell, and there cannot be comforted, distinguished from how he is taken out of hell and brought into heaven (TG, 1949:XI); the old man distinguished from the new man (TG, 1949:CVI), and so forth.

A close reading of the Theologia Germanica shows, however, that the Frankfurter takes the Perfect and "that which is in part" as the two poles between which the human subject moves, either closer towards unification with Absolute Being or towards "self-ness" or "Iness" (TG, 1949:13). In Aristotelian parlance the Perfect (or Essence) of all things is in itself unchangeable and immovable, yet it

25 Luther quotes St. Paul's statement to the effect that "(t)he invisible things of God from the creation of the world are clearly seen, being understood by the things that are made, even his eternal power and Godhead". 
changes and moves all things else (TG, 1949:113). To the Frankfurter it is axiomatic that God moves the world as an unmoved mover through his pure being - "as the beloved moves the lover" (Task in TG, 1949:229 n. 4). Absolute Being reveals itself as the Highest Good to all human beings: "God, who is the highest Good", does not wish to hide Himself from anyone (TG, 1949:114).

The human subject's "receiving of the Creator" (or becoming unified with absolute Being) is relative to "putting off the creature" (TG, 1949:114). This implies that not all human beings are unified to the same extent with Absolute Being: "For in what measure we put off the creature, in the same measure we are able to receive the Creator; neither more nor less" (TG, 1949:114). Furthermore, the measure of departure from "I-ness" or "self-ness" determines the measure of "heat" and "light" entering the mind and will of the human subject $(T G, 1949: 114)$. Stated in other terms, this means that the measure of acknowledgement of and submission to Absolute Being is determinate for the illumination experienced by and measure of union accomplished with the Absolute Good (or Absolute Being). The acknowledgement of and submission to Being is not possible by virtue of the actions (or initiatives) of human "I-ness" or "self-hood" as long as the human subject rationally comprehends and cleaves to "I-hood", "creature-nature", "desire", so long the Perfect remains unknown to the human subject (TG, 1949:115).

The acknowledgement of and submission to Absolute Being is not the only requirement for proceeding on the path of unification with Absolute Being. He who submits to God and desires to be obedient must submit to all being, that is to say, to God, his own self and all created beings (TG, 1980:88). The Frankfurter postulates it as an undeniable truth that the human subject should be surrendered to God's hands and surrender to all creatures and fellow beings, "not in terms of outer activity but in terms of inner compassion" (TG, 1980: 107). It is noteworthy that the Frankfurter subscribes to and places the emphasis on the idea of universal being - not the discrete being of this creature and that, but all essences in themselves as partial substances. This idea of universal being, then, to the Frankfurter, is the point of departure.

The implications of the Frankfurter's views on the acknowledgement of and submission to universal being relative to the human subject's union with the Absolute Good, are of far-reaching importance. These implications concern the knowledge of moral good in the lives of Christians and non-Christian believers in particular. Although God's revelation, through his universal divine "Essence" (or Being), de- 
mands acknowledgement and submission on the part of all human beings, not all of them follow this light. Only where human "self" or "I-ness" is overcome by acknowledging and submitting to universal being, does the light break through, so to speak.

The Frankfurter also draws a clear distinction between the idea of being illuminating the human mind, and natural reason. Whereas natural reason is concerned with human "I-ness" or "self-ness", the idea of being is actually the avenue through which God's revelation comes to the human subject. The idea of being intuits that which is it is the idea of what exists; the idea of being is an innate idea, not to be confused with the subjective "I-ness" or "self-hood" of the human subject. It serves as a transcendent, objective form; it illuminates without becoming the eyes of the beholder; it is the known object which enlightens the known subject. The light of being, therefore, acts as a revelatory power and provides the mind of the human subject with the knowledge to reason; it is the basic judgement (or fundamental idea) in which all others are grounded. The formal element of the idea of being consists in the light which illumines; the material component is contained in the revelatory power of being. Through the knowledge, love and will, the human subject is able to relate and execute the judgements accumulated as a result of the light contained within the reason of the human subject. The Frankfurter states this as follows: if the human subject did not have knowledge, will and love, he/she would be just like "cattle-dumb beasts" (TG, 1980:64). If the human subject acknowledges and submits to being in its order - the fact that all created being issues from Absolute Being - he/she would have inner knowledge and indeed know that he/she is not God (TG, 1980:65). Through submitting and acknowledging being in its order, the human subject can grasp eternity in temporal existence relative to proceeding on the path of unification with God (cf. TG, 1980:68). On this point the Frankfurter quotes from Dionysius who held that in order to behold a divine mystery, the human subject should detach him-/herself from the sensual (human "I-ness") and all that the senses can grasp and reason comprehend and know (TG, 1980:68). 26

The measure of the human subject's submission to universal being is not only determinate for his/her unification with absolute Being, it

26 The quotation is from Dionysius the Areaopagite's Concerning mystic theology, I, 1. Other aspects of Dionysius' views of graded ascent to the heavenly world were not shared by Luther, for example see Hoffman (1975:24). 
is also determinate for avoiding trust in natural reason. By not following the light of universal being, natural man clings to the natural reason and his own "self"; natural "I-ness" clings to the enjoyable, free, careless life - he holds on to natural reason, extracts pleasure from his self, his selfhood, his own kind of peace, his own doings, and all that belongs to the self, because where natural reason holds sway "it climbs so high in its own light and in itself" that it fancies itself to be the eternal true light "and it passes itself off as precisely that" (TG, 1980:84). However, this "high and learned natural reason" deceives and draws with it in the same deceit others who do not know better and are also inclined in that direction (TG, 1980:84).

Two further aspects need attention: firstly, the human subject's progress on the way to unification with the Absolute Being is not his/her own work or merit, but results from being "drawn" by God's Spirit; and, secondly, the idea of universal being shines with a revelatory light and testifies with a revelatory power from outside the mind or reason of the human subject. This implies that due to the measure of the non-Christian subject's acknowledgement of and submission to universal being, he/she may gain knowledge of the moral good and produce virtuous acts of serving the neighbour in love. In practical terms this entails that in Luther's moral view the efforts of unregenerated human beings may be relatively "righteous" in the realm of creation, even while they remain wholly unacceptable in the realm of redemption (Lazareth, 1967:181).

The primary question concerns the nature of the idea of being in non-Christians. The idea of being intuits that which is - it is the idea of that which exists. The idea of being (both Absolute Being and created being) serves as the point of departure (the form of the human subject's intellective faculty) in the form of an innate idea, not to be confused with the "I-ness" or "self" of the human subject - it is a transcendent, objective form. Like a light, it illuminates without becoming the eyes of the beholder; it is the known object which enlightens the knowing subject. The light of being is "transmitted" to the mind of the human subject. This revelatory power of being is the first act with which the mind reasons; this is the basic judgment in which all others are grounded. The formal element of the idea of being consists in the light which illumines; the material component is contained in the revelatory power of being. Through man's knowledge, will and love, the human subject is able to relate and execute the judgments accumulated as a result of the light contained within the reason of the human subject. 
If the human subject submits to and acknowledges being in its order (the order of the nature of things), he/she would have true inner knowledge and indeed know that he/she is not God (TG, 1980:65). Through submission to and acknowledging being in its order, the human subject can grasp eternity in temporal existence (TG, 1980:68). The Frankfurter refers to Saint Dionysius, who held that in order to behold a divine mystery, the human subject should detach himself from the sensual and all that the senses can grasp and reason comprehend and know (TG, 1980:68). 27 The human reason needs the light of being in order to perceive that everything it desires is nothing compared to that which has always been desired (TG, 1980:71). Submission to being entails that the human subject should be concerned with his own self as little as though he did not exist; "he should view all created things from the same point of view" (TG, 1980:76).

By not following the light of being, natural man clings to the natural reason. To natural man no life is as comfortable and enjoyable as a free, careless life - he holds on to natural reason, extracts pleasure from his self, his selfhood, his own kind of peace, his own doings, and all that belongs to the self. This happens most of all where high natural reasoning holds sway, "for it climbs so high in its own light and in itself" that it fancies itself to be the eternal true light "and passes itself off as precisely that" (TG, 1980:84). However, this "high and learned natural reason" deceives and draws with it in the same deceit others who do not know better and are also inclined in that direction (TG, 1980:84).

Does the light of being in the human intellect have moral consequences? The Frankfurter establishes a direct link between the light of being in the human mind and man's moral behaviour in the earthly domain. The moral deportment and commands in the earthly realm are the outflows of the light of being in the following way: the obligations and rules of earthly life must be in keeping with and an outflow of the true light.

But that which does not represent such a 'must' or such an 'ought' but rather flows from sheer egoistic desire cannot be in keeping with the true Light. Man often invents for himself many musts and oughts that are actually false. (TG, 1980:85.)

27 Other aspects of Dionysius, the Areopagite's views of graded ascent to the heavenly world were not shared by Luther (cf. Hoffman, 1975:24). 
Submission to the idea of being in its order carries as a consequence the willingness to be obedient, to serve and to be submissive to God; furthermore, it produces the willingness to serve, to be obedient and submissive to the created world, in a spirit of compassionate yielding, "and not in a spirit of busyness". Because it is characteristic of created beings and the natural order that they seek, in all they commit and omit, wherever, the advancement of self and the concerns of self (TG, 1980:88). When a person surrenders and abandons his own self, God enters with his Own, that is, his Self (TG, 1980:90).

On a philosophical level it should be noted that the Frankfurter's views on the idea of being are analogous in some respects to the views of the German critical philosophers, to the extent that some innate element is necessary, and not categories or subjective forms. The German critical philosophers, therefore, share the Frankfurter's contrary position to that of the British empiricists' rejection of ideas and universals, for example, and their refusal to grant anything to the intellect except sensations.

For the unredeemed human subject submitting to the idea of being, the light of reason, not reason, constitutes an essential moral guide in the temporal domain. The idea of being whose light is used by reason provides the human subject with moral knowledge. Reason is the power using the light - if it is confused with the light it falsely takes on the excellence and infallibility of the light. This makes reason proud and self-reliant, and the human becomes both legislator and god in the moral universe. To ignore the light of reason (reason's divine element) is to debase human beings by denying them a true moral state - they are either condemned to perpetual error, or to groping in the darkness for the truth they can never be certain of finding.

\subsubsection{Luther on the ethical, the mystical and non-Christians in the order of creation}

Does the presence of the light of reason make any meaningful difference in the moral environment in the world? What does the acknowledgement of the light of being have to offer non-Christians in the order of creation? Is it possible for non-Christians to perform virtuous deeds? Before considering the details of Luther's answers to these questions, it has to be noted that Luther maintains that nonbelievers in Christ can also perform morally virtuous acts in the domain of creation. However, the nature of virtue in the lives of Christians and non-believers has to be distinguished. 
In his Lectures on Genesis, Luther explains in much detail the fact that non-Christians are also able to gather knowledge of and perform morally good actions. He singles out a number of non-Christians "of the better sort" regarding their morally good actions and their wisdom in the moral domain. The Roman philosopher Cicero is a good example of Luther's respect for the moral insights of nonChristians in the moral domain. Luther lauds Plato and Cicero as examples of those philosophers who attributed reason to man, thereby elevating man above the ordinary animals and viewing man as a being created for immortality ( $L W, 1$ (LG), Gen. 2:22). However, only in the light of Scriptures can the human subject gain true knowledge, not only about the form of creation, but also about the efficient and final causes of the entire creation; "about the beginning and about the end of all things, about who did the creating and for what purposes He created" (LW, 1 (LG), Gen. 2:22). Although the light of human reason casts light on the formal cause of creation, without the knowledge of the efficient and final cause, human wisdom does not differ much from that of the beasts ( $L W, 1$ (LG), Gen. 2:22).

The divide between true knowledge obtained only through the Word and faith on the one hand, and moral knowledge obtained through the light of reason in the earthly domain, on the other, surfaces constantly in Luther's writings. Although the human subject may have great wisdom in matters pertaining to morals, only through the Word and faith does he/she have true knowledge and insight ( $L W, 1$ (LG), Gen. 2:22). A number of important implications flow from the implicit distinction between the true knowledge the human subject can only obtain through the Word and faith on the one hand, and the knowledge gleaned through the light of reason (or right reason) in the order of creation. Firstly, regarding moral duties, although Cicero and Livy may have had the ability to depict human behaviour in lofty style, only in Scripture do we find an adequate description of human actions (LW, 1 (LG), Gen. 4:9). Although Aristotle in his Nicomachean ethics and Cicero in his treatise On duties may have stated the theory of duties owed by man, the Holy Scriptures teach ethics, or the theory of duties, far better than they do ( $L W, 2$ (LG), Gen. 12:13). In a particularly instructive portion of his Lectures on Genesis, Luther explains the reasons why the non-Christians are prevented from obtaining true knowledge in the spiritual domain. 28

28 This does not prevent non-Christians from having insights regarding what God is in Himself or his innermost Essence (i.e. his Being). Luther wrote: 
Alluding to Aquinas' (1997) statement in his Summa (ST, (P)I-II, $\mathrm{Q}(76)-\mathrm{A}(3)$ ), Luther states that Cicero's lack of knowledge of God is "invincible". When you read his treatises De natura deorum and De finibus bonorum et malorum, according to Luther, you realise that he has omitted nothing that mankind is able to attain by means of human reason and all of its powers; yet he does not know what God's will is - the ability to know God does not come from our innate reason, but from the Spirit of God, who enlightens our minds through the Word. Since Cicero lacked this, he had to struggle with a lack of knowledge that was invincible (LW, 2 (LG), Gen. 12:17). Although Cicero did the best he could, says Luther, he did not obtain grace:

... yes, his study hurled him into deeper darkness, so that he actually had doubts about the existence of God. When anybody ponders such lofty matters without the Word and relies solely on the light of reason, his errors inevitably become progressively greater (LW, 2 (LG), Gen. 12:17).

In effect Luther is saying that even though the human subject may have the benefit of the light of reason, there are limitations to the knowledge gleaned by that light, particularly when it pertains to matters of grace and salvation ( $L W, 2$ (LG), Gen. 12:17). Luther surmises that whereas the Holy Spirit reveals man's true destiny and purpose on earth, philosophy does not have this insight. Luther refers to Cicero's inability in his De natura deorum to understand why the situation in this life is so unfair that the wicked flourish, while the pious fail even in their most honourable efforts and plans. Luther responds by stating that reason looks only at the adversities of the present and is impressed and overwhelmed by them, while of the promise concerning the future it has no knowledge at all. The Holy Spirit, however, commands us to disregard the things of the present and to look at those of the future ( $L W, 2$ (LG), Gen. 12:16). Because natural reason is wholly incompetent to provide the human subject with true knowledge of God, even the virtuous deeds performed by

The natural reason itself is forced even here where there is no holy scripture to grant it [namely the truth that the general human reason possesses many true cognitions of what 'God is in himself or in his innermost essence'], convinced by its own judgment. For all men, as they hear it treated of, find this belief written in their hearts, and acknowledge it as proved, even unwittingly: first, that God is omnipotent and can neither err nor be deceived ... (WA, 18:719, 20-26; LW, 33:191 (CR III); trans. Hoffman, 1976:144).

This implies a presupposed knowledge of God pre-naturally impressed upon man's mind - without any acquaintance with the arts and sciences - providing all human beings with the knowledge that God is. 
non-Christians are not the results of their natural reason; only through God, with his Spirit, can they perform virtuous deeds ( $L W, 2$ (LG), Gen. 8:22). Although, therefore, Plato, Cicero and Socrates are all very great men, they do not have the faith in the gospel for true knowledge, and those who do not believe the gospel are not the church; "nor do they belong to the kingdom of Christ" ( $L W, 5: 269$ (LG), Gen. 21:16; also see LW 2:(LG), Gen. 29:3; LW, 26:123 (LGS I)). Elsewhere Luther puts it even more strongly: non-Christians may have the light of reason but - like Socrates and Cicero - do not know that they are born children of wrath (Eph. 2:3) and are subject to original corruption, because the healthier, more learned, and wiser human beings are, the more pride and other sins do they have. They never penetrate to the "true light of Scripture" and the kingdom of Christ ( $L W, 7: 281$ (LG), Gen. 42:34). Any person who ventures to learn something about God by means of his reason will find that the longer the human subject seeks, the farther he/she is from the goal; only by clinging to the Word does the human subject find the mark ( $L W, 24: 72$ (SJ III), John 14:10). Only by clinging to Christ is the human subject justified - refraining from murder or adultery, whether done by natural powers or by human strength or by free gift and power of God, does not justify him/her ( $L W, 26: 123$ LGS (I), Gal. 2:16).

Secondly, the knowledge gained through the light of reason (or right reason) has high value in the order of creation because the relative value of the morally good knowledge or actions of some nonChristians sometimes reflects a high level of truth in the order of the world. Luther alludes to Cicero's 29 "truth" statements in his De amacitia (XVI, 59), to the effect that friendships cannot exist where people are given to suspicion; also to Aristotle's designation in his Nicomachean ethics (IV, 7), of truth as the mother of love, because neither households nor governments can last without truth ( $L W, 2$ (LG), Gen. 12:13). The light of reason may provide wonderful insights in the order of creation, $\mathbf{3 0}$ but it cannot provide true know-

29 For Luther's high estimation of Cicero's works, cf. LW (54:171 (TT), collected by Conrad Cordatus, no. 2808b: Cicero in comparison with the Scriptures between November 24 and December 8, 1532). Also cf. LW (54:243 (TT), recorded by Anthony Lauterbach \& James Weller, no. 3608e: A comparison of Aristotle and Cicero between June 18 and July 28, 1537).

30 Cf. Luther's statements in LW (26:123 n. 40 (LGS I)); and his remarks in LW (26:354 (LGS I), Gal. 3:28) to the effect that among the Gentiles there were many great and outstanding men, viz. Xenophon, Themistocles, Marcus Fabius, Antilius Regulus, Cicero, Pomponius Atticus and many others, endowed with 
ledge about God or man, for example the scholastic theologians have been captivated by philosophical fancies and have failed to preserve the true knowledge either of God or of themselves $(L W, 2$ (LG), Gen. 8:22). For this reason they have fallen into fearful errors. Indeed, says Luther, the fall is easy after one has departed from the Word, "for the lustre of civil virtues captivates the minds in a marvellous manner" (LW, 2 (LG), Gen. 8:22). Luther cites the example of Regulus, who lacked the knowledge of God, although he did what was right, for with his zeal to help his fatherland there was combined a desire for glory, in other words, human "I-ness" or "self-ness". Regulus scorned life in order thereby to gain immortal fame among later generations:

If one considers the 'phantom' of life and the outward mask, his was a most noble deed; but before God it is rank idolatry, for Regulus appropriates to himself the glory for this deed. And who has any doubt that other vices were connected with this eagerness for glory? ( $L W, 2$ (LG), Gen. 8:22.)

Although, therefore, great men may perform virtuous deeds, when you look at their minds, you see that they were motivated in this by nothing but the desire for glory ("I-ness" or "self-ness") ( $L W, 12: 309$ (SP I), PS. 51:1).

Luther also rates very highly the worth of the books written by wise men on secular government - these works have even become the sources of ancient imperial laws. According to God's providence God gave and preserved such heathen books by Homer, Virgil, Demosthenes, Cicero, Livy and the "fine old jurists", that the heathen and godless, too, might have their "prophets, apostles, and theologians or preachers" for secular government, even as the people of God had their Moses, Elijah, Isaiah, and others; "and the emperors, kings, and princes, like Alexander, Augustus, et cetera, were their Davids and Solomons" (LW, 13:199 (SP II), Ps. 101:5). Just as the spiritual and holy prophets and kings taught and directed the people about how to come to the eternal kingdom of God and to remain in it, so these secular, heathen, godless prophets and kings

excellent, in fact heroic virtues, administering their commonwealths very well and accomplishing many brilliant things for the welfare of the commonwealth. Yet all their wisdom, power, honourable deeds, outstanding virtues, laws, righteousness, worship and religion amounted to nothing in the sight of God. Therefore, in spite of all the virtuous deeds of the great men and the value of their insights in the order of creation, everything they accomplished regarding domestic, political, and divine justice, amounts to nothing in the order of redemption (LW, 26:354 (LGS I), Gal. 3:20). 
taught and directed the people about how to preserve the secular kingdom. Because God had willed to give temporal dominion to the heathen or to reason, $\mathrm{He}$ also had to provide people who had wisdom and courage, who had the necessary inclination and skill, and who would preserve it. In the same way He always had to give his people teachers who were able to rule his Christian church and to do battle against the devil. All sorts of books, laws and teachings have been produced by these two groups; the heathen have their heathen books, Christians have the books of Holy Scriptures. The former teach virtue, laws, and wisdom with respect to temporal goods, honour, and peace on earth; the latter teach faith and good works with respect to eternal life in the kingdom of heaven ( $L W$, 13:199 (SP II), PS. 101:5).

Thirdly, the divide between philosophy and theology corresponds to the two forms of knowledge: right reason (the light of reason) in the order of creation and true knowledge in matters of faith respectively. Although philosophical knowledge in the order of creation may be very valuable for preserving civil peace (expressed for example in the works of Cicero and Scipio), it remains insufficient for the salvation of the human person ( $L W, 34: 142$ (CR IV), The disputation concerning man). The value of the work of the Romans is situated in the fact that they contributed much towards preserving the peace and maintaining public tranquillity; so also Cicero and Scipio are called righteous, because they punished "frightful crimes" in the republic and took measures against villains even though in the order of redemption their persons did not please God (LW, 34:170 (CR IV), The disputation concerning justification). The pagan philosophers and poets teach much that is useful and valuable about temporal virtues - they teach that man is obliged to serve his fellow man, to keep faith also with his enemies, and to be loyal and helpful especially in time of need:

Thus Cicero and his kind teach. Indeed, I believe that three of Aesop's fables, half of Cato, and several comedies of Terence contain more wisdom and instruction about good works than can be found in the books of the Talmudists and rabbis and more than may ever occur to the hearts of the Jews. ( $L W$, 47:227 (CS IV), On the Jews and their lies.)

The truth and virtue in the domains of the order of redemption and the order of creation respectively are different in kind and matter. So for example no philosopher, neither Plato nor Cicero, admits that the incarnation is a possibility and neither does he tell how this world began, because philosophy deals with visible matters while theology 
deals with invisible ones ( $L W, 38: 249$ (W\&S IV), The disputation concerning the passage: "the Word was made flesh"). There is also a distinction to be made in regard to the word upright - there are upright persons in theology and there are upright persons in philosophy. Whereas the philosophical uprightness is meant for a mother and a father, there is a more excellent uprightness in theology, so that Luther here differentiates civil (or philosophical) uprightness from the uprightness demanded by God ( $L W, 38: 259$ (W\&S IV), The disputation concerning the passage: "the Word was made flesh"). Whereas philosophy inquires into the reasons of many things concerning the order of creation, it cannot inquire into matters of faith and the Word ( $L W, 38: 259$ (W\&S IV), The disputation concerning the passage: "the Word was made flesh"). Philosophy deals with matters that are understood by human reason, theology deals with matters of faith - that is, matters which are apprehended by faith ( $L W, 38: 262$ (W\&S IV), The disputation concerning the passage: "the Word was made flesh"), although philosophy and theology are not contrary to one another ( $L W, 38: 267$ (W\&S IV), The disputation concerning the passage: "the Word was made flesh"). Therefore, firstly, philosophy does not allow us to argue in the mysterious articles of faith, but we must adhere strictly to the word and truth of the Bible. The judgement of reason is not enough to oppose the word upheld by faith, but reason should subordinate and submit itself to the obedience in Christ. Secondly, "man", "flesh", and so forth, become designations with new meanings when they refer to Christ, different from when they are approached philosophically ( $L W, 38: 277$ (W\&S IV), The disputation concerning the passage: "the Word was made flesh").

Fourthly, the knowledge and the virtues reflected by great men who have right reason and wisdom are imperfect. The civic honesty that manifests itself in word and deed flowing therefrom accordingly, also has many faults mingled with it. Thus, Pomponius, Atticus, Aristedes and Socrates were honest and guileless men, and there have been many honest husbands among the heathen, who marvellously preserved the faithfulness they had pledged to their wives. There may also have been honest merchants - all these examples of civic honesty and "daily examples" are required by God and show that this civic honesty cannot be transgressed with impunity - yet this honesty is not pure, if we consider the judgment of God; "there are many filthy vices clinging to it, and God requires a much greater honesty". Although there may be works of righteousness (justice) among Turks, Jews, and papists outside the Word of God, all this righteousness and this holiness is a lie, which God does not love, 
but which He most thoroughly hates and curses. God condemns all human wisdom with all human holiness and righteousness, for God loves or requires "hidden truth" - truth should apply to a person's total life (LW, 12:353 (SP I), Ps. 51:7). Although, therefore, Aristedes and Pomponius had a good name among their fellows, the truth that God loves is not exposed to the eyes this way, "it is in secret and hidden" ( $L W, 12: 353$ (SP I), Ps. 51:7); it is hidden under the appearance of holiness, just as truth lies hidden, until it is denounced by the Word, and this hidden truth is revealed ( $L W, 12: 353$ (SP I), PS. 51:6). 31

Fifthly, there are marked differences among human beings regarding the knowledge they obtain through the light of reason. In his Lectures on Genesis, Luther observes that even though he rates Aristotle above Cicero in native ability, so he realises that Cicero, in his De natura deorum $(1,13)$, discussed issues related to man's destiny on earth with far greater discernment than did Aristotle ( $L W$, 2 (LG), Gen. 11:1). In worldly matters the non-Christians often have more outstanding talent and greater learning than the Christians or the people of God, and the children of the world are wiser than the children of the light (Luke 16:8; cf. LW, 33:87 (CR III), The bondage of the will).

Sixthly, true knowledge in the order of redemption goes much higher than the mere teaching of moral duty. Those people, says Luther, who remain standing on the teaching of the law are actually nothing but heathens, who learn nothing else than to know what they ought to do. For those who do not want to proceed beyond the mere knowledge of what they ought to do, it would be enough to provide Cato's poem on Aesop whom he considers "the better teacher of morals" ( $L W, 2$ (LG), Gen. 9:20; also note $L W, 13: 200$ n. 5 (SP II)). This also means that the virtues of the heathen must be distinguished from the virtues of Christians. Although it is true that the hearts of both are prompted by God, among the heathen the zeal and ambition for glory eventually "corrupt these divine impulses

31 Also note Luther's remarks on Psalm 101:1 - the value of great and noble wisdom is limited and has limited use. Such thoughts of worldly wisdom may even be harmful and destructive; therefore, even wise and well-meaning persons have ruined land and people. All this Luther says of the self-wise rulers whom God did not direct and to whom He gave no success, but who still wanted to be leaders. Thus, the burden of government has been too great an assignment for them, and they have not been able to do justice or to carry it out; they have been "crushed under it" and have perished, as did Cicero, Demosthenes, Brutus and others (LW, 13:165 (SP II), Ps. 101:1). 
in great men" ( $L W, 2$ (LG), Gen. 8:22). Luther adds the following explanation applying Aristotelian terminology: if an orator should undertake to elaborate on the efficient cause, but should disregard this final, depraved case, "who does not see that once the two chief causes, the formal and the final, are disregarded, this wretched shadow of virtue can be embellished by an eloquent man?" ( $L W, 2$ (LG), Gen. 8:22). It also implies that, although the efficient cause is virtuous, its virtue is corrupted by the desire for glory, thus the formal cause and the final cause are wrong and these are decisive. The deception, says Luther, will be readily perceived by a dialectician he is aware that the formal cause, that is, right reason, is lacking inasmuch as there is no knowledge of God and no right will toward God. Moreover, he is aware that the final cause is corrupt, for the true goal, obedience towards God and love of one's neighbour, receives no consideration. Luther concludes by asking:

What sort of virtue is it where nearly all the causes are missing except the natural one, which is only something passive, that is, a drive or impulse by which the heart is moved to keep faith with an enemy? Even the ungodly have these drives, therefore if they are followed in behalf of the fatherland, they become virtues; if against the fatherland, they become vices, as Aristotle learnedly argues. (LW, 2 (LG), Gen. 8:22; cf. also Aristotle, Politics, III, 5.)

With reference to Genesis 8:22 ("For the imagination of man's heart is evil from his youth"), Luther observes that human nature is corrupt, although there may be "semblances of virtue" which occur among the heathen, and which may create the impression that something has been left unimpaired in nature ( $L W, 2$ (LG), Gen. 8:22). Quoting the example of the poet Terence's statement in his work Andria (1.1.51), to the effect that "(i)t is man's nature to incline away from exertion towards sensuality", Luther states that reason per se does not prescribe what is right, nor does the will per se desire what is right, as blind philosophy argues, which does not know the origin of these "fearful impulses" (LW, 2 (LG), Gen. 8:22).

Seventhly, Luther explicitly rejects those mystical views based on the notion that natural reason or the union of the human intellect and will can accomplish a union of man with God. So, for example, Luther denounces as speculation the idea of graded ascent preached by Dionysius ( $L W, 54: 112$ (TT), no. 644: The defects of speculative or mystical theology, Fall, 1533). Luther also rejects those mystical views that hold that it is possible for man to rise above being and non-being ( $L W, 54: 112$ (TT), no. 644: The defects of speculative or 
mystical theology, Fall, 1533) because God is everything and everywhere, but also unknown and nowhere. God is not apprehensible through speculations, but only through his revelation in the Word and through his works ( $L W, 54: 35$ (TT), no. 257: God is unknowable and yet known; between April 20 and May 16, 1532). God is apprehensible to those who follow the light of reason - God is only manifest to those who submit to his universal Being. Also, because God is everywhere and nowhere, He is excluded from no place and $\mathrm{He}$ is confined to none. To Luther God is not only potentially everywhere - God is in every creature in both ways because God does not act through his properties, but through his Being ( $L W$, 54:32 (TT), no. 240: The omnipresence of God; between April 7 and 15, 1532). Although the submission to universal being may provide us with the light of reason in the moral sphere, this is not enough for the justification of the human person - only through faith and the Word can man be justified and unified with Christ.

\section{Conclusions}

To Luther, Christians and non-Christians have much in common: both function and work in the order of creation; both have to apply reason in furthering their understanding of the natural world; both have to ascend through rational reflection to the formulation of general concepts necessary for scientific endeavour; both come to postulate predicates in a rationally coherent way through reflection, judgement and the identification of that which is intellectually sound and valid; both can attain high levels of excellence in their moral views; and so forth. The knowledge regarding sound moral behaviour gleaned by both Christians and non-Christians alike is attainable by acknowledging and submitting to God's universal revelation through the order of being in God's world.

The moral posture required for respecting being universally, reflects attitudes radically different to the existing culture in the socio-moral domain. So, for example, the "spiritual humility" required from human beings demands submission to God and all creatures, and does not seek freedom in the spirit that the human subject has a right to everything (cf. TG, 1854:54-55). On the other hand, "it is necessary and useful that there should be ordinances and customs, laws and commandments, that thereby blindness may be taught, and wickedness forced under rule"; if that were not the case, humans "would become worse and more disorderly than dogs or other animals" (TG, 1854:55-56). This principle finds support in Luther's thought that the enforcement of law and order are not contrary to the 
demands of love, and God's love manifests itself through God's restraints through law to curtail the actions of evil (WA, 11:250). It also means that through laws, commands and ordinances natural man must be brought to greater respect for universal being.

God's universal revelation is generally accessible to all human subjects and demands submission to the order of being. The universal testimony of God in creation cannot be escaped by the human subject - the idea of being inherent in God's universal revelation has a force and a power that demands acknowledgement and submission to being universally by the human subject. Such acknowledgement of and submission to the idea of being in God's revelation on the part of the human subject, find their parallels in the Ciceronian notion of acting in accordance with the exigency of things in their order, in other words right reason. Acting in accordance with right reason is tantamount to acting according to the light of reason, which light is nothing other than the idea of being.

Within the Occamist structure of Luther's views on knowledge, philosophy is a very useful tool to the aid of mankind in the natural sphere to both Christians and non-Christians alike. However, in the supra-natural sphere (the sphere of faith) all the fruits of reason and the whole of human knowledge acquired through the intellect are insufficient to come to the true knowledge for the redemption of the human soul and for attaining eternal life. The proto-argument of Luther's approach is found in the statements of the Frankfurter. The Theologia Germanica describes the true knowledge needed for man's salvation in terms of a mystical unification of man with Christ, only attainable through faith and the Word. No human knowledge obtained through natural reason can accomplish this mystical unification with Christ - it can only be experienced through the Word and the faith in Christ.

Therefore, the Occamist views on knowledge provide Luther with the broad divide between theological and philosophical knowledge. The theological sphere is only attainable by Christians experiencing the mystical unification with Christ. In the philosophical sphere useful (and even morally sound) knowledge and the reaping of the fruits of the application of such knowledge are possible by submitting to God's universal revelation in the form of the idea of being.

A number of important implications emanate from Luther's mystical and Ciceronian perspectives within the broad Occamist division of knowledge. The first is that both Christians and non-Christians should work together to oppose all forms of evil and to promote be- 
nevolence among all human beings. Secondly, one has to work actively in and engage with non-believers in furthering the message of the Word and faith in God's world. Thirdly, in the domain of politics and law all human beings have the duty to promote respect for their fellow human beings, to further justice and to behave in a morally virtuous way in all human relationships. In these respects Luther's synthesis provides valuable perspectives for considering the promotion of peaceful human co-existence in the world and in particular societies.

\section{List of references}

AQUINAS, T. 1997. (ST) Summa Theologica. (In Schaff, P., ed. Mater Christian Library: the Nicene and Post-Nicene Fathers. First Series, Vol. 2. Trans. by M. Dods. Albany: Books for the Ages.)

BERNHART, J. 1966. Die Philosophische Mystik des Mittelalters. München: Reinhardt.

BUNSEN, C. . 1854 Letter. http://www.ccel.org/print/anonymous/ theologia/iv Date of access: 28 Jan. 2009.

FRANKFURTER. 1854. Old German theology. Trans. Mrs. Malcolm. London: Hall \& Virue.

FRANKFURTER. 1874. Theologia Germanica. Trans. S. Winkworth. London: Macmillan.

FRANKFURTER. 1901. Theologia Germanica. Trans. S. Winkworth. London: Macmillan.

FRANKFURTER. 1949. Theologia Germanica. Trans. W.R. Trask. New York: Pantheon.

FRANKFURTER. 1980. The Theologia Germanica. Trans. B. Hoffman. London: SPCK.

HÄGGLUND, B. 1955. Theologie und Philosophie bei Luther und in der Occamistischen Tradition. Lund: Gleerup.

HARKNESS, G. 1942. Nothing burneth in hell but self-will. The Christian century, 59(7):216-218.

HOFFMAN, B.R. 1974. Luther and the mystical. Lutheran quarterly, 26(3):316329.

HOFFMAN, B.R. 1975. On the relationship between mystical faith and moral life in Luther's thought. Bulletin, Lutheran Theological Seminary at Gettysburg, 55(1):21-35.

HOFFMAN, B.R 1976. Luther and the mystics: a re-examination of Luther's spiritual experience and his relationship to the mystics. Minneapolis: Augsburg.

HOFMANN, G., ed. 1961. Johannes Taulers Predigten. Freiburg: Herder.

JOHNSON, W.C. 1985. "Three Godly witnesses": depictions of the trinity in the works of Hendrik Niclaes and the Theologia Germanica. Mennonite quarterly review, 59(1):24-41.

JOHNSON, W.C. 1988. The mystical tradition of the Homo Deificatus in the theology of the family of love and the Theologia Germanica, 1(2):1-24. 
LAZARETH, W.H. 1966. Luther on civil righteousness and natural law. (In Asheim, I., Hrsg. Kirche, Mystik, Heiligung und das Natürliche bei Luther. Göttingen: Vandenhoek \& Ruprecht. p. 180-188.)

LUTHER, M. 1883-1987. Werke: kritische Gesamtausgabe. 78 Bde. Weimar: Hermann Böhlaus Nachfolger.

LUTHER, M. 1958-1967. Works. 55 vols. Eds. J. Pelikan (vols. 1-30) \& H. $L W$ Lehmann (vols. 31-55). Philadelphia: Concordia.

see LUTHER, M. 1958-1967

OTTO, R. 1975. The idea of the holy: an inquiry into the non-rational factor in die idea of the divine and its relation to the rational. Trans. J.W. Harvey.

TG London: Oxford University Press. see FRANKFURTER

TINSLEY, E.J. 1952. The Theologia Germanica: the nature of Christian WA mysticism. The church quarterly review, 304:84-88.

see LUTHER, M. 1883-1987

\section{Acronyms used}

$\mathrm{CR}=$ Career of the Reformer

$\mathrm{CS}=$ The Christian in society

$L G=$ Lectures on Genesis

LGS = Lectures on Galatians

$\mathrm{SJ}=$ Sermons on the Gospel of St. John

$\mathrm{SP}=$ Selected Psalms

$\mathrm{TT}=$ Table talk

$W A(B r)=$ Briefwechsel

$W A(\mathrm{Tr})=$ Tischreden $)$

$\mathrm{W} \& S=$ Word and sacrament

\section{Key concepts:}

Cicero

idea of being

Luther

mysticism

\section{Kernbegrippe:}

Cicero

idee van syn

Luther

mistisisme 
